\title{
Family businesses and employment relations: Review and suggestions for future research
}

\author{
PAUL WOODFIELD*, ERLING RASMUSSEN ${ }^{* *}$ and YASHIKA \\ CHANDHOK $^{* *}$
}

\begin{abstract}
This paper seeks to identify and summarise the big issues at the intersection of family businesses and employment relations business literatures. Family businesses have additional complexities compared with non-family businesses. Thus, the aim of this paper is to throw light on why this intersection is of interest in New Zealand and rationalise the need to research employment relations in the context of family businesses. We first present family businesses as an area for research by outlining the landscape of family businesses in New Zealand, followed by a review of the foundations of family business and employment relations research. We then highlight and discuss three overarching themes: familiness or family dynamics; formalisation/professionalisation; and incorporating employment relations perspectives. Finally, we conclude with future research directions and canvas potential research questions to introduce ways researchers can enhance our understanding of employment relations in family firms.
\end{abstract}

Keywords: Employment relations; family business; family firm; governance; long-term orientation; human resource management, HRM.

\section{Family business as a context for research}

Family business research has been an area of interest for decades; however, it is still a young discipline which is now distinguished and explored separately from its contemporary disciplines (Neubaum, 2018a). Family business research was originally considered a subset of the entrepreneurship research, but over the past few years, this research area has developed organically with overlapping literature from the field of behavioural sciences, particularly as part of organisational behaviour (Neubaum, 2018a; Payne, 2018; Teixeira et al., 2020).

With family business research becoming a distinct area to study, researchers have been working toward developing a definition of a 'family business' which encapsulates all its attributes (Tagiuri \& Davis, 1996). While there is no agreed definition which encompasses the totality of family businesses, the following definition by Chua et al. (1999) creates the base of this review in that family businesses are defined as:

\footnotetext{
* Senior Lecturer, AUT Business School, Auckland University of Technology, New Zealand

** Professor and PhD student, AUT Business School, Auckland University of Technology, New Zealand

Contact: paul.woodfield@aut.ac.nz
} 
... a business governed and/or managed with the intention to shape and pursue the vision of the business held by a dominant coalition controlled by members of the same family or a small number of families in a manner that is potentially sustainable across generations of the family or families (p. 25).

This definition highlights the influence of family beyond ownership and management and includes its impact on the business's missions, goals, communication patterns, conflict management, long-term orientation and much more (Payne, 2018).

\section{Family businesses in New Zealand}

Research in the New Zealand family business landscape is sparse. This is evident in the completion of only a few $\mathrm{PhD}$ studies centred on exploring family businesses in New Zealand (e.g. Hirsch, 2013; Kilkolly-Proffit, 2016; Woodfield, 2012) that has produced related research articles (Hirsch, 2011; Kilkolly-Proffit, 2013; Woodfield \& Husted, 2017; 2019; Woodfield et al., 2017a; Woodfield et al., 2017b). Over the past few decades, there have been other research articles and reports published in an ad-hoc manner; however, these have mainly concentrated on small businesses or small- and medium-sized entreprises (SMEs) with references to family businesses (de Bruin \& Lewis, 2004; Keating \& Little, 1997; Lewis et al., 2005; New Zealand Government, 2016). Typically, family business surveys carried out internationally have been spearheaded by consulting firms, including KPMG (2018) and PwC (2016; 2021), accounting firms, such as MGI International (2007; 2013), and banks, including ANZ's privately-owned firms' survey (ANZ, 2013). These surveys have often been conducted in partnership with universities. On the other hand, there is very little reference to family businesses on government websites or reports as they are typically under the umbrella of small businesses or SMEs (e.g. Small Business Council, 2019).

Overall, academic and practice-based research in the family business area is simply lagging in New Zealand and falling behind the rest of the world in contributing to the global discussion. A key exception was made in 2005 by the Employers and Manufacturers Association (EMA), who funded research into family businesses. The rationale was simple-much of their clientele are family-owned and managed. Largely, this funding went to scholarships for doctoral and master's students and supporting researchers to focus on family businesses. The overall lack of research is surprising given that family businesses make up approximately 70 per cent of businesses in New Zealand (MGI, 2007; Whittaker et al., 2011). Internationally, it is estimated that family firms contribute between 70 to 90 per cent of global GDP (McKinsey \& Company, 2014; Tharawat, 2016).

It is important to break the perception that family businesses are distinguished by firm size, (that is, SMEs). Some of the world's largest and most prominent businesses are owned and controlled by families, for example: Walmart, BMW, Dell, Mars, Dyson, Bacardi, McCain Foods, and Red Bull (Family Capital, 2021; Jiang \& Peng, 2011; Peng \& Jiang, 2010; Peng et al., 2018). In New Zealand, numerous large firms are owned and managed by families, such as the Todd, Goodman, Gough, Huljich, Barfoot and Thompson, Mills, and Talley families (Anthony \& Nadkarni, 2020), many of which are in traditional industries, for example, primary, manufacturing, engineering, and service industries (Hirsch-Kreinsen, 2015; Woodfield \& Husted, 2017). These large multi-generational firms are anchored in New Zealand although sometimes they take on different ownership forms as they outgrow the traditional ownermanager model and take control through the governance of their shareholdings in numerous firms, rather than single entities as is often the case with SMEs. Moreover, family SMEs 
anchored in New Zealand may consider selling to overseas interests and not realise their growth and potential toward becoming a larger firm. There are obvious economic and social benefits if SMEs stay and grow in New Zealand, so there is impetus to nurture SMEs toward becoming larger.

Even more sparsely researched - not only in New Zealand but overseas as well - is the intersection between family businesses and employment relations. In particular, we will elaborate on the complex family business culture and use this to clarify, and set up, the intersection between family business and employment relations. We will then draw upon and incorporate existing family businesses and employment relations literatures. This will include key family business concepts, such as 'familiness' and family dynamics, formation and professionalism; we will also canvas employment relations concepts, such as collective bargaining and statutory employee rights as well as literature on human resource management (HRM) practices. Ultimately, this paper will identify key areas of research and narrow down the gap in the literatures pertaining to family businesses and employment relations. In highlighting the gaps in these literatures, we offer practical implications for future research in this field, including potential research questions.

\section{Family business, work, and employment relations}

As family business research was founded on entrepreneurship research, the application of agency theory and stewardship theory remain popular to understand the role of top management in family businesses (Eddleston et al., 2018; Payne, 2018). Some of the other theories that have been widely applied to family business literature are upper-echelons theory (Craig et al., 2014), resource-based theory (Habbershon \& Williams, 1999), social capital theory (Pearson et al., 2008), institutional theory (Soleimanof et al., 2018), family and social identity theory (Miller \& Le Breton-Miller, 2006). An important foundation of family business research is recognising that both "family business and work-family research study the intersection and spillover of the family and business/work domains. This research demonstrates how both fields of study can gain insight from the other" (Baù et al., 2020, p. 2).

Craig et al. (2014) proposed a model reflecting the relationships between family influence and firm performance and learnt that family influence has an impact on developing and maintaining the organisational culture of family businesses. Family business cultures are found to have flexible planning systems based on their idiosyncratic resources and capabilities, positively affecting a firm's innovativeness. This innovativeness influences a firm's performance by providing a competitive advantage to the organisation that is deeply rooted in the family's culture and beliefs (Craig et al., 2014). While this model captures the essence of family's influence on a firm's performance, the linearity of the model does not delve deeper in explaining how the family exhibits this influence.

Moreover, Moskovich \& Achouch (2017) throw light on the complex family business culture which includes "development of human resources management, labour relations, working climate in business, health, safety, prosperity, fulfillment of regulatory requirements for employees, equal opportunities, and any other matter relating to the employment relationship, which goes beyond just the employees" (p. 97). At this juncture, we realise the evolution of family business research goes beyond the formation of the business and toward the formulisation of the business with the usual complexities of a corporation and the added complexities of familial ties. 
Whilst writing his reflections on family business research, Payne (2018) highlighted that the family business literature lacks a complex theory and a comprehensive framework that clearly defines the boundaries of this field. In an attempt to clarify and build towards the same, Payne (2018) presented a framework to explain the complex interdependence and link between the family and business. The framework (Figure 1) builds a general overview depicting how the basic antecedents or characteristics of a family can impact the goals, values, or cognitions of the business and vice-versa.

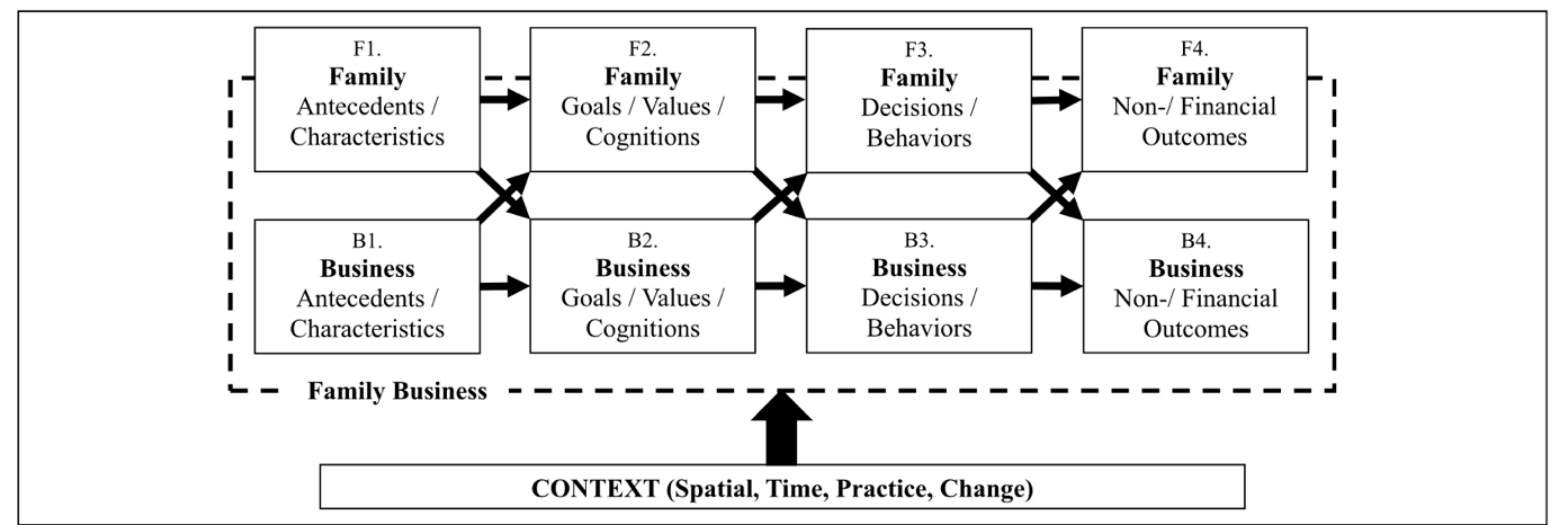

Figure 1: Framework for understanding the link between family and businesses (Payne, 2018)

Neubaum (2018a) addressed one of the limitations of this model by recognising that family and business systems are not independent of each other but are related and overlapping components which cannot be presented individually. He extended the model (Figure 2) by emphasising the interdependence, overlap and relatedness of the two structures.

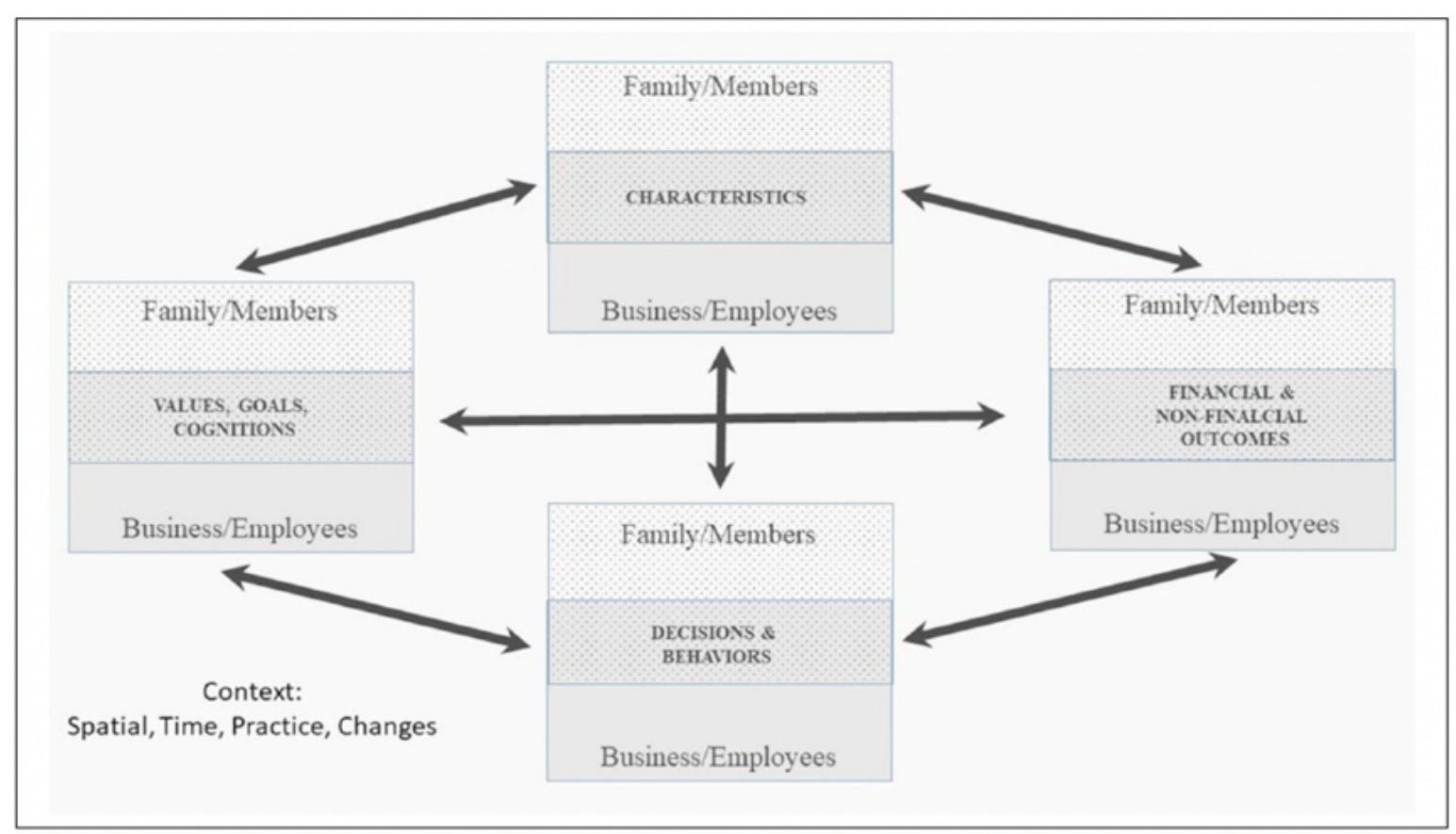

Figure 2: Updated framework for understanding the link between family and businesses (Neubaum, 2018a)

Payne (2018) also acknowledged that the biggest weakness of his model is that it does not include an individual component. The model focuses on the firm-level data and neglects the impact of various individuals, family or non-family members, which is "an important area of inquiry that we should revisit" (Payne, 2018, p. 31). While Neubaum (2018a) tried to address this gap by including the words "employees and members" in his model, Payne's (2018) review 
of Family Business Review Journal (FBR) calls on researchers to take larger leaps to develop new theories considering explicit constructs which improve our understanding of their influence on family businesses.

The following sections aim to elucidate the intersection between family businesses and employment relations through three overarching themes: Familiness and Family Dynamics; Formation and Professionalism; Incorporating Employment Relations Perspectives.

\section{Familiness or Family Dynamics}

The concept of familiness - often called family harmony or family dynamics - acknowledges the importance of strong familial networks, both within and outside an organisation that impact the goals and success of the family business (Block \& Wagner, 2014; Ram \& Edwards, 2003). Family harmony captures how the family members get along with each other as their strong compatibility results in high commitment and extra-role behaviours (Eddleston et al., 2018). A family business creates a sense of pride for its members as not only a source of their livelihood, but reflecting values and goals that builds a family's socio-emotional wealth (SEW), that is, "... non-financial aspects of the firm that meet the family's affective needs, such as identity, the ability to exercise family influence, and the perpetuation of the family dynasty" (GómezMejía et al., 2007, p. 106), and reputation in public (Block \& Wagner, 2014; Lamb et al., 2017; Soleimanof et al., 2018).

Family businesses that emphasise both family and business have enjoyed successful performance within the business, personal satisfaction, and public reputation (Rantanen \& Jussila, 2011). The following research directions reflect familiness and family dynamics themes accounting for different interpersonal relationships in family businesses compared to non-family businesses.

\section{Family-Collective Psychological Ownership (F-CPO)}

Psychological ownership or "a state of mind experienced by the individual holding a feeling of possessiveness" (Rantanen \& Jussila, 2011, p. 140), is a phenomenon experienced by both family and employees in a family business. Collective psychological ownership (CPO), on the other hand, is defined as the "...collectively held sense among members of a group that a target of ownership (or a piece of that target) belongs to the group as a whole" (Rantanen \& Jussila, 2011, p. 141). Strong ownership feelings amongst employees drive the socio-economic wealth (SEW) of the organisation by increasing employee motivation and commitment and enhancing job performance (Rantanen \& Jussila, 2011; Teixeira et al., 2020). Family employees in a business often experience strong CPO as they identify with the organisation's goals and values as they intertwine with the family's goals and values, creating an overlapping social and individual identity (Henssen et al., 2014; Rantanen \& Jussila, 2011).

\section{Overlapping social and organisational identity}

Moreover, Block and Wagner (2014) define family identity as "the meaning that family members attach to the family as an institution. This meaning includes specific types of interpersonal relationships and behavioural expectations that are attached to these relationships" (p. 478). The literature suggests that family firms have a strong sense of family identity which is inseparable from the organisation that generates the feeling of an overlapping social identity (Lamb et al., 2017; Rantanen \& Jussila, 2011). A family business is not just a 
source of economic wealth and wellbeing, but a source for reflection and enjoyment to the family, which allows them to create memories to pass down to future generations (Rantanen \& Jussila, 2011). It gives family members a purpose and ties their public identity and reputation to the organisation. Due to this overlap, the goals, cognition and values of a family often overlap with that of the family business (Payne, 2018).

This overlap makes family business owners follow non-economic goals like family cohesiveness, pride, autonomy, and control (Block \& Wagner, 2014), or as Lamb et al. (2017) state: "A family firm is governed by both a familial logic, which is characterised by a focus on socio-emotional wealth, kinship dynamics, and family control, and a business logic, which is focused on efficiency, competition, and profit-maximisation" (p. 481). Strong family identity develops informal communication, fostering expedited transfer of knowledge and experiences amongst family employees. Most of the research in this area has focused either on the family as a whole or specifically on the organisational leader (Rantanen \& Jussila, 2011). However, the development of the identity of non-family employees and their effort in understanding and becoming a part of the familial values and structure remains under-researched (Block \& Wagner, 2014).

\section{Employee and family relationships}

Baù et al. (2020) conducted a review to analyse the impact of family embeddedness with career processes and outcomes, and developed a model depicting the family embeddedness perspective on careers in family businesses. They recognised that family business research focuses on the family members but overlooks various transitions in the family system. Transitions like marriage and divorce significantly influence the intra-organisational relationships as well as resources of the family, affecting the family firm's and individual's performance outcomes (Baù et al., 2020). With this in mind, we can link family embeddedness with employment relations.

Kang and Kim (2020) conducted a recent study to compare if family firms invested more in development and implementation of employee-friendly policies than non-family firms. They asserted that most of the family firms realise that strong employee relationships give them a unique competitive advantage in the market. The results of their study confirmed that the longterm orientation of family business owners and the strong interdependence of the family's reputation on the business are the main factors, resulting in the high investment in employeefriendly policies in family businesses (Kang \& Kim, 2020; Miller \& Le Breton-Miller, 2006). Family business leaders pay more attention to their employees to avoid any disputes and controversies, which can hamper the reputation of the family. Kang and Kim (2020) note that family business owners do not struggle with managerial myopia as long-term orientation is the base of the organisation. Thus, managers often maintain the traditional paternalistic employeeemployer relationship where the employer acts as a caretaker (in line with the Stewardship Theory) and prioritise strong employee-employer relationships.

This research resonates with Tabor et al.'s (2018) review of family businesses and their nonfamily employees where they postulated that strong family harmony and embeddedness to the organisation has shown to have a positive influence on the non-family employees. This closeknit culture provides a caring climate where the family business owners display stewardship behaviour for the whole organisation (Tabor et al., 2018). This can also be the cause of increased feelings of psychological ownership for non-family employees (Bernhard \& O'Driscoll, 2011). New family businesses invest the most in employee-friendly policies, which 
changes with the formalisation of the business and, thus, Bernhard and O'Driscoll (2011) call for a longitudinal empirical research to uncover strong causal effects about the same.

\section{Trust, commitment, and altruistic behaviours}

Psychological ownership, identity, and relationships are informed by altruistic behaviours and trust. Eddleston et al. (2010) state that: "Families throughout the world offer naturally occurring communities that generate trust relations" (p. 1044) and thus, family businesses provide a strong avenue for research under the paradigm of trust and governance. Altruistic behaviour limits conflict and strengthens one's relationship with the organisation.

However, high altruism can also result in role ambiguity, leaving employees dependent on the leader for cues (Bernhard \& O'Driscoll, 2011). It also raises questions of employee justice and, if left unresolved, weakens the competitive advantage of the family businesses (Rantanen \& Jussila, 2011). Eddleston and Morgan (2014) also questioned the lack of establishing causal relationships between the transfer of commitment and trust from family to business domain.

\section{Formalisation/ Professionalisation}

High involvement of family members, entrepreneurial zeal from the family firm leader and, open and confrontational communication channels can develop an 'informal' organisational culture in family businesses (Eddleston et al., 2018; Ram, 2001). This informality can be reflected in a form of 'informal' employment relationships which is defined as: "a process of workforce engagement, collective and/or individual, based mainly on unwritten customs and the tacit understandings that arise out of the interaction of the parties at work" (Ram, 2001, p. 846). Professionalisation remains a popular theme in the family business literature. However, little attention has been paid on understanding how informality evolves in family businesses as they grow (Ram et al., 2001).

Research about governance structures in family businesses have alluded to conflicting results (Goel et al., 2012). Mustakallio et al. (2002) found that family businesses with independent board members are able to make quality strategic decisions towards the growth of the organisation as their advice and decision-making focuses on organisational goals and wealth more than the SEW. However, Schulze et al. (2001) state that independent board representation influenced the sales growth of family businesses negatively as the 'outsiders' focused on the business aspect of the family business while overlooking the relational aspect of families. Research analysing the influence of intertwining subjects of governance, formalisation, and trust on the relationship amongst the employees of family businesses can provide strong propositions for future research. The following research directions are themes presenting gaps in our knowledge relating to formalisation and professionalisation.

\section{Communication patterns}

Constructive confrontation refers to communication patterns and decision-making norms that embrace open expression, cooperation, and personal acceptance (Eddleston et al., 2018). Eddleston et al. (2018) asserted that family business leaders need to implement such a communication channel wisely as the firms where the constructive confrontation was paired with high monitoring, family employees felt discouraged and reduced extra-role behaviours (ERB). In other words, when constructive confrontation is highly monitored, this could lead to 
inertia in family employees going beyond their primary role. However, if used cautiously, constructive confrontation encourages collaborative problem-solving and greater ERB for family employees, thus, family employees taking the initiative to go beyond their primary role. This is particularly true when conditions, including family harmony and adaptability, are present in the family firm.

\section{Knowledge sharing}

The communication pattern adopted in family businesses can have a direct influence on the knowledge sharing in the organisation. Frequent informal communication amongst the family members both, inside and outside the organisation, results in constant and progressive sharing of knowledge (Miller et al., 2006). Senior members of an organisation should construct a participative and stimulating culture which facilitates knowledge sharing across hierarchies (Husted \& Michailova, 2002).

Research in family business literature has typically focused on incumbents' knowledge and its transfer though mentoring (Woodfield \& Husted, 2017). Past research hints at the relevance of employment relations from the perspective of knowledge sharing when there is rivalry amongst the family members, and unresolved conflicts can result in knowledge hoarding (Husted \& Michailova, 2002). However, it has been restricted to the senior generation's role of holding the tacit knowledge only (Eddleston \& Kellermanns, 2007). Woodfield and Husted (2017) highlight the importance of research on 'bidirectional knowledge sharing' which has received little attention in family business literature. They argue that while the founding generation brings tacit knowledge to the organisation, the succeeding generation contributes to the organisation's knowledge by bringing explicit knowledge acquired thorough formal education, internships, and training with outcomes, including innovation and entrepreneurship.

\section{Hierarchy and decision-making}

Small family firms are often characterised by an organisational structure featuring a strong concentration of managerial control with the owner/manager. This can limit the opportunities for employees to exercise personal power and autonomy over their work (Bernhard \& O'Driscoll, 2011). Family members influence the decision-making process by shaping the organisational vision and mission with the family's identity (Teixeira et al., 2020). However, small structures also offer close proximity between an organisation's top management and other members. With low standardised procedures, protocols and bureaucracy, small family businesses give an opportunity to its employees to participate in the decision-making process. This, in turn, leads to the positive feeling of ownership and autonomy to the employees, increasing the job commitment and task performance (Rantanen \& Jussila, 2011). However, if employees participate in the decision making, it is dependent on the leadership practices adopted by the senior management (Henssen et al., 2014). It is also important to note which employees have a say and whose opinion counts during decision making in family businesses (Block \& Wagner, 2014; Lamb et al., 2017).

\section{Conflict resolution and management}

Conflict resolution is a vital part of both family business and employment relations literature. Kubíček and Machek (2020) conducted a systematic literature review of intrafamily conflict in family businesses and affirmed that even though family firms are considered 'fertile lands for conflicts', there is not much about conflict in family businesses. Their review reflected that past empirical research lacked in integration of strong conflict management or negotiation 
theories as conflict was not the main focus of most of the research. Intragroup conflict can be categorised into relationship conflict, task conflict and process conflict (Kubíček \& Machek, 2020). Relational conflict has been the most prominent in both fields of literature as it often overlaps with a task or process conflict. Mallet and Wapshott (2017) claimed that informality, strong relationships, and commitment of employees advocates for higher job satisfaction and low rates of disputes in small family businesses.

\section{Incorporating Employment Relations Perspectives}

In the employment relations literature, there is scant attention given to family firms beyond research on SMEs. With the dramatic changes to employment relations in recent decades, and with these changes arguably being more dramatic in New Zealand than in other OECD countries, there are many avenues that current and future research could take.

The decline in collective bargaining over the last three decades (Blumenfeld \& Donnelly, 2017), including the award system being abolished by the Employment Contracts Act 1991, has meant that most firms have had a relatively free hand to establish their own employment relations arrangements (Rasmussen et al., 2016). This has been particularly so amongst SMEs where unions have seldom featured at all. For example, Foster and Farr (2016) found in their research on positive employer-employee interactions in respect of employment relations arrangements in SMEs that most employers took a paternalistic approach with limited use of participative processes. Whether this would also be the case across firm sizes amongst familyowned businesses is an interesting, still to be explored, research question. Furthermore, this free hand of employers may be constrained in the future as the post-2017 governments have enhanced statutory minima and collective bargaining rights (see below), including the recent announcement that legislation about Fair Pay Agreements will be introduced in 2021. Overall, the key point is that there is little research about whether family businesses differ in their employment relations arrangements from non-family businesses.

On the other hand, the decline in union density and collective bargaining coverage has coincided with a rise in statutory employee rights. These rights are expected to be applied across the workforce regardless of firm size and whether firms are family-owned or nonfamily-owned. While many countries have enhanced employee rights through an increase in, or an introduction of statutory minima, this has been pronounced in New Zealand. In New Zealand, there has been a strong rise in the statutory minimum wage since 2017 as well as in other employee entitlements (for example, the doubling of sick leave entitlements in 2021). Additionally, with a personal grievance (PG) right covering most employees (Anderson et al., 2020), this entitlement could have a significant impact on the managing of employees within family businesses. The general question is whether family firms have experienced particular issues or trends in respect of these employee rights. Unfortunately, the short answer is that we know preciously little about what, if anything, separates family businesses from non-family businesses.

Moreover, it is essential, from an employment relations perspective (see Bamber et al., 2016), to incorporate an evaluation of the existing research on the prevailing mix of HRM strategies, process, and practices both internationally and in New Zealand. As discussed below, there are certain HRM areas in family firms which have been researched and they will provide us with a starting point for future research on family firms and employment relations. 
Human Resource Management has been an important theme across the family business research where researchers have focused on understanding how professional or familial management impacts the HRM systems in family businesses (Neubaum, 2018b; Ram \& Edwards, 2003; Ram et al., 2001; Stewart \& Hitt, 2012; Tabor et al., 2018). These studies have specifically focused on recruitment and promotion, training and growth opportunities, compensation structures and work-life balance of the employees. However, the focus of the research has been the top-level management, including both family employees and non-family CEOs.

Generally, the HRM literature could benefit from a wider perspective since it is essential to understand the full impact of the prevailing mix of HRM strategies, process, and practices that goes beyond particular HRM areas, such as recruitment strategies (if any), and the training and growth opportunities on both family and non-family firms and their employees. Another intriguing aspect of research under this spectrum is to understand and recognise the unpaid work of non-working family members, especially women. In their critique on the research interest revival of SMEs from an employment relations perspective, Mallet and Wapshott (2017) found that, in some family business setups, the women of the family took care of the children while the other members managed the family business experience. This traditional work arrangement is often maligned in the literature but can have the advantage of creating a better work-life balance for some family members.

The following research directions are existing literature themes that are closely related to employment relations perspectives and specific HRM areas and arguably they need to be further researched to better incorporate the two literatures.

\section{Recruitment and promotion of employees}

Family firms are often associated with nepotism where the bloodline of the founder often dictates succession (Stewart \& Hitt, 2012). Family firms provide an appropriate setting for the younger generations to explore their career choices and uncover their entrepreneurial skills (Baù et al., 2020), and gain knowledge that can be shared within the family business (Woodfield \& Husted, 2017). The majority of the literature in this area focuses on the succession and transgenerational leadership of family employees, however, researchers like Lamb et al. (2017) and Sieger et al. (2011) focused on the non-family members to understand which type of non-family members are recruited by the family firms and the criterion used by the family firms for their selection. Lamb et al. (2017, p. 473) posited that family firms have a tendency to promote people who "look or behave" like the family members. As family firms often carry the same name as that of the family, the resulting overlap of identities affects the recruitment strategies of the employees (Block \& Wagner, 2014).

\section{Training and growth opportunities}

Younger generation of families who own and/or manage a family organisation are conditioned towards the business from a very young age (Rantanen \& Jussila, 2011). They observe and experience their family's struggle and hard work towards building and maintaining the organisation which works as 'everyday training' helping the children develop their firmspecific skills, long-term commitment, and aspiration for the growth of the organisation (De Massis et al., 2013; Tabor et al., 2018; Teixeira et al., 2020; Woodfield \& Husted, 2017). However, Tabor et al. (2018) alluded that training and growth opportunities available to nonfamily employees are limited in family organisations. While Kang \& King (2020) posited that family firms tend to invest more in employee-friendly policies, Chrisman et al. (2014) 
suggested that family firms suffer with lack of training and inadequate compensation of nonfamily employees due to personalised onboarding and performance evaluations. The skills developed under the work of family businesses also tend to be firm-specific due to the idiosyncratic culture of these organisations. This results in decreased motivation of non-family employees and thus, there is a gap in knowledge related to addressing how family bias influences recruitment and training procedures in family businesses (Tabor et al., 2018).

\section{Gender equity}

Another topic of interest under this research paradigm is the experiences of female family employees. Female family employees experience the job satisfaction, wages, discrimination, and growth opportunities differently to male family employees working in the same organisation (Block \& Wagner, 2014; Block et al., 2015). Gender issues challenge traditions in family businesses where decisions regarding promotion of a daughter's career reinforces glass-ceilings constructed in various cultures (Akhmedova et al., 2020; Kilkolly-Proffit, 2013; Kubíček \& Machek, 2020). Block et al. (2015) and Kubíček and Machek (2020) call for longitudinal research to understand the differences of male and female family employees regarding career opportunities, discrimination, compensation, and the role of females in family businesses as a whole.

\section{Work-life balance}

The supportive work-home culture of family organisations is known to provide a relaxed atmosphere which increases the satisfaction and wellbeing of family employees (Mallett \& Wapshott, 2017; Moskovich \& Achouch, 2017). In research carried out on family-owned restaurants in the UK, Ram et al., (2001) posited that family businesses provided flexibility to employees where the employees were happy to cover for each other as they understood their family needs better. However, the research around this topic has not been the focus of family business research and could reflect on the impact of unpaid work conducted by women of family businesses as well as the work-life balance of all family employees.

\section{Influence of religion, culture, and family structures}

Lastly, little attention has been paid to the influence of religion, culture, and family structures across countries and/ or different societies in understanding the workings and growth of family business enterprises (Neubaum, 2018a; Stewart \& Hitt, 2012). Kubíček and Machek (2020) suggest the application of Hofstede's cultural values or GLOBE's (Global Leadership and Organizational Behavior Effectiveness) cultural practices to support closing gaps in our knowledge relating to family businesses. While the research of Hofstede and GLOBE have attracted some controversy, it can still be interesting, as these structures and cultural systems form the base of employment, or rather family relationships, to understand the impact of these cultural and institutional structures on employment relationships in family businesses.

\section{Future research}

We have established that there are several issues at the intersection of the family business and employment relations literatures. At the forefront, family businesses have been established to be different from 'other' non-family businesses. In the New Zealand context, family businesses make up most SMEs and are thus worthy of more research attention. Moreover, often forgotten is that there are numerous large firms owned and managed by families. With family businesses 
often viewed within a spectrum of size, the 'small is beautiful' (Rainnie, 1989; Wu, 2020) perspective embedded in New Zealand's culture can cause inertia in growth and have negative consequences for the professionalisation of firms. Rather that SMEs anchored in New Zealand selling to overseas interests, we need to explore how they can be nurtured so they can realise their growth and potential, thus providing longer term economic and social benefits for the New Zealand society.

Related to business growth, paternalism can be seen as an asset in the earlier phases of a business where a need for strong, driving features are needed, but as the firm grows and matures, the paternalistic nature can become less functional and more of a liability (Chirico et al., 2012). There is an opportunity for future research to focus on business growth where, for example, governance and employment relations need to be formalised and professionalised. Furthermore, the relationship between family business growth, the moving away from paternalism, and the shift toward standard employment relations, warrants further research attention.

By gaining insights on how family and employee relationships differ from non-family businesses we are exploiting a gap where potential research directions and questions can be canvassed, shedding light on key areas that could be developed further. From our three overarching themes: Familiness and Family Dynamics; Formation and Professionalism; Employment Relations Perspectives, we derived a few areas warranting further research (refer Table 1). First, under the familiness and family dynamics theme, we propose that these is little research on how collective psychological ownership (CPO) differs between family and nonfamily employees and how non-family employees build their identity within family businesses. Second, under the formalisation and professionalisation theme, better understanding the way family employees receive and respond to knowledge shared by non-family employees is an avenue for further exploration.

Moreover, how can non-family employees influence decision-making and conflict resolution within a family business? As explained earlier, we need to nurture family businesses through their growth which includes applying appropriate employment processes that scaffold their growth. Naturally, attention needs to be paid to processes and practices in larger family businesses, recognising the additional complexities compared with non-family businesses. Finally, there are possibilities to explore the criteria applied by a family business both in employment relations strategies and arrangements as well as within particular HRM areas, including recruiting, promoting, and training of non-family employees.

There is already a need to build on the existing frameworks to integrate employment relationships. Payne (2018) acknowledged this need to develop new theories to improve our understanding of the impact on individuals - both family and non-family members - in family businesses. Moreover, the individual component of the family business framework needs to build upon the employment relationship literature which acknowledges the complexity of the relationship amongst the leader, family employees, non-family employees and other nonemployee family members in a family business (Bernhard \& O'Driscoll, 2011; Neubaum, 2018a; Rantanen \& Jussila, 2011). These relationships influence key factors within family businesses including communication patterns, conflict resolution, and overlapping individualorganisational identity. As such, these offer an avenue for research which is yet to be explored. 
Table 1: Potential research questions based on themes at the intersection of family business and employment relations

\begin{tabular}{|c|c|c|}
\hline & Sub-theme & Research Question (RQ) \\
\hline \multirow{4}{*}{$\begin{array}{l}\text { Familiness or } \\
\text { Family Dynamics }\end{array}$} & $\begin{array}{lr}\text { F-CPO } & \text { (Family- } \\
\text { Collective } & \text { Psychological } \\
\text { Ownership) } & \\
\end{array}$ & $\begin{array}{l}\text { How does the feeling of CPO differ amongst } \\
\text { family and non-family employees? }\end{array}$ \\
\hline & $\begin{array}{l}\text { Overlapping social and } \\
\text { organisational identity }\end{array}$ & $\begin{array}{l}\text { How do the non-family employees build their } \\
\text { identity in family businesses? }\end{array}$ \\
\hline & $\begin{array}{l}\text { Employee and family } \\
\text { relationships }\end{array}$ & $\begin{array}{l}\text { How do transitions or family events like marriage } \\
\text { or divorce influence the organisational structure } \\
\text { and culture of family businesses? }\end{array}$ \\
\hline & $\begin{array}{l}\text { Trust, commitment, and } \\
\text { altruistic behaviours }\end{array}$ & $\begin{array}{l}\text { What is the role of leaders of family businesses } \\
\text { in development of trust and commitment } \\
\text { amongst non-family employees? }\end{array}$ \\
\hline \multirow{4}{*}{$\begin{array}{l}\text { Formalisation/ } \\
\text { Professionalisation }\end{array}$} & Communication patterns & $\begin{array}{l}\text { How do non-family employees respond to the } \\
\text { constructive confrontation style of } \\
\text { communication in family businesses? }\end{array}$ \\
\hline & Knowledge sharing & $\begin{array}{l}\text { How do family employees receive and respond to } \\
\text { the knowledge shared by outsider or non-family } \\
\text { employees in a family business? }\end{array}$ \\
\hline & $\begin{array}{l}\text { Hierarchy and Decision } \\
\text { Making }\end{array}$ & $\begin{array}{l}\text { How can non-employee family members } \\
\text { influence the decision making of a family } \\
\text { enterprise? }\end{array}$ \\
\hline & $\begin{array}{l}\text { Conflict resolution and } \\
\text { management }\end{array}$ & $\begin{array}{l}\text { How do non-family employees perceive conflict } \\
\text { amongst the family members in a family firm? }\end{array}$ \\
\hline \multirow{5}{*}{$\begin{array}{l}\text { Incorporating } \\
\text { Employment } \\
\text { Relations } \\
\text { Perspectives }\end{array}$} & $\begin{array}{l}\text { HRM processes in family } \\
\text { businesses }\end{array}$ & $\begin{array}{l}\text { What criteria are applied by family businesses } \\
\text { when recruiting non-family employees? How do } \\
\text { these criteria differ from employing family } \\
\text { members? }\end{array}$ \\
\hline & $\begin{array}{l}\text { Training and Growth } \\
\text { Opportunities }\end{array}$ & $\begin{array}{l}\text { How can family business leaders provide a } \\
\text { stimulating organisational culture to the non- } \\
\text { family employees who have not received family } \\
\text { tacit knowledge compared to the family } \\
\text { employees? }\end{array}$ \\
\hline & Gender equity & $\begin{array}{l}\text { How do family business leaders promote male } \\
\text { and female family and non-family employees in } \\
\text { a family business? }\end{array}$ \\
\hline & Work-life balance & $\begin{array}{l}\text { Do non-family employees enjoy the same } \\
\text { flexibility and work-life balance available to the } \\
\text { family employees in a family business? }\end{array}$ \\
\hline & $\begin{array}{lcr}\begin{array}{l}\text { Influence } \\
\text { culture, } \\
\text { structures }\end{array} & \text { and } & \text { religion, } \\
\text { family }\end{array}$ & $\begin{array}{l}\text { In what ways does religion, culture and family } \\
\text { structures influence the relationships with non- } \\
\text { family employees? }\end{array}$ \\
\hline
\end{tabular}




\section{References}

Akhmedova, A., Cavallotti, R., Marimon, F., \& Campopiano, G. (2020). Daughters' careers in family business: Motivation types and family-specific barriers. Journal of Family $\begin{array}{lll}\text { Business } & \text { Strategy, } & 100307 .\end{array}$ https://doi.org/https://doi.org/10.1016/j.jfbs.2019.100307

Anderson, D., Rasmussen, E., \& Foster, B. (2020). The major parties: National's and Labour's employment relations policies. New Zealand Journal of Employment Relations, 45(1), 3-13. https://doi.org/10.24135/nzjer.v45i1.13

Anthony, J., \& Nadkarni, A. (2020, January13). How to build a multi-generational business. Stuff. https://www.stuff.co.nz/business/118529448/how-to-build-a-multigenerational$\underline{\text { business }}$

ANZ. (2013). ANZ Privately-Owned Business Barometer: Key Insights 2013. https://www.anz.co.nz/resources/3/1/31c30e89-c10e-456c-89f2ccb21107a9e7/POBB-KeyInsights-2013.pdf?MOD=AJPERES

Bamber, G. J., Lansbury, R. D., Wailes, N., \& Wright, C. F (Eds.). (2016). International and comparative employment relations: national regulation, global changes ( $6^{\text {th }}$ ed.). Allen and Unwin.

Baù, M., Pittino, D., Sieger, P., \& Eddleston, K. A. (2020, 2020/09/01/). Careers in family business: New avenues for careers and family business research in the 21 st century. Journal of Family Business Strategy, 11(3), 100379. https://doi.org/https://doi.org/10.1016/j.jfbs.2020.100379

Bernhard, F., \& O’Driscoll, M. P. (2011). Psychological Ownership in Small Family-Owned Businesses: Leadership Style and Nonfamily-Employees' Work Attitudes and Behaviors. Group \& Organization Management, 36(3), 345-384. https://doi.org/10.1177/1059601111402684

Block, J., \& Wagner, M. (2014, 12//). Ownership versus management effects on corporate social responsibility concerns in large family and founder firms. Journal of Family $\begin{array}{lrr}\text { Business } & \text { Strategy, } & \text { 5(4), } \\ \text { https://doi.org/http://dx.doi.org/10.1016/j.jfbs.2014.08.005 }\end{array}$

Block, J. H., Millán, J. M., Román, C., \& Zhou, H. (2015). Job Satisfaction and Wages of Family Employees. Entrepreneurship Theory and Practice, 39(2), 183-207. https://doi.org/10.1111/etap.12035

Blumenfeld, S., \& Donnelly, N. (2017). Collective Bargaining Across Four Decades: Lessons from CLEW's Collective Agreement Database. In G. Anderson, A. Geare, E. Rasmussen, \& M. Wilson (Eds.), Transforming Workplace Relations in New Zealand 1976-2016 (pp. 107-128). Victoria University Press.

Chirico, F., Nordqvist, M., Colombo, G., \& Mollona, E. (2012). Simulating Dynamic Capabilities and Value Creation in Family Firms: Is Paternalism an "Asset" or a 
“Liability"? Family Business Review, 25(3), 318-338. https://doi.org/10.1177/0894486511426284

Chrisman, J. J., Memili, E., \& Misra, K. (2014). Non-family managers, family firms, and the winner's curse: The influend of non-economic goals and bounded rationality. Enterpreneurship Theory and Practice, 38(5), 1103-1127. https://doi.org/10.1111/etap.12014

Chua, J. H., Chrisman, J. J., \& Sharma, P. (1999, 1999/07/01). Defining the Family Business by Behavior. Entrepreneurship Theory and Practice, 23(4), 19-39. https://doi.org/10.1177/104225879902300402

Craig, J. B., Dibrell, C., \& Garrett, R. (2014). Examining relationships among family influence, family culture, flexible planning systems, innovativeness and firm performance. Journal of Family Business Strategy, 5(3), 229-238. https://doi.org/https://doi.org/10.1016/j.jfbs.2013.09.002

de Bruin, A., \& Lewis, K. (2004). Toward enriching united career theory: Familial entrepreneurship and copreneurship. Career Development International, 9(7), 638-646. https://doi.org/10.1108/13620430410570347

De Massis, A., Chirico, F., Kotlar, J., \& Naldi, L. (2013). The Temporal Evolution of Proactiveness in Family Firms: The Horizontal S-Curve Hypothesis. Family Business Review. https://doi.org/10.1177/0894486513506114

Eddleston, K. A., Chrisman, J. J., Steier, L. P., \& Chua, J. H. (2010). Governance and trust in family firms: An introduction. Entrepreneurship: Theory and Practice, 34(6), 10431056. https://doi.org/10.1111/j.1540-6520.2010.00412.x

Eddleston, K. A., \& Kellermanns, F. W. (2007). Destructive and productive family relationships: a stewardship theory perspective. Journal of Business Venturing, 22(4), 545-565. https://doi.org/10.1016/j.jbusvent.2006.06.004

Eddleston, K. A., Kellermanns, F. W., \& Kidwell, R. E. (2018). Managing Family Members: How Monitoring and Collaboration Affect Extra-Role Behavior in Family Firms. Human Resource Management, 57(5), 957-977. https://doi.org/https://doi.org/10.1002/hrm.21825

Eddleston, K. A., \& Morgan, R. M. (2014). Trust, commitment and relationships in family business: Challenging conventional wisdom. Journal of Family Business Strategy, 5(3), 213-216. https://doi.org/http://dx.doi.org/10.1016/j.jfbs.2014.08.003

Family Capital. (2021). The World's 750 Biggest Family Businesses. https://www.famcap.com/the-worlds-750-biggest-family-businesses/

Foster, B. \& Farr, D. (2016). Some willingness to engage: A survey of employment relations practices and employee voice opportunities in SMEs in regional New Zealand. New Zealand Journal of Employment Relations, 46(1): 41-64.

Goel, S., Mazzola, P., Phan, P. H., Pieper, T. M., \& Zachary, R. K. (2012). Strategy, ownership, governance, and socio-psychological perspectives on family businesses from around 
the world. Journal of Family Business Strategy, 3(2), 54-65. https://doi.org/10.1016/j.jfbs.2012.03.005

Gómez-Mejía, L. R., Haynes, K. T., Nunez-Nickel, M., Jacobson, K. J. L., \& Moyano-Fuentes, J. (2007). Socioemotional wealth and business risks in family-controlled firms: Evidence from Spanish olive oil mills. Administrative Science Quarterly, 52(1), 106137. https://doi.org/10.2189/asqu.52.1.106

Habbershon, T. G., \& Williams, M. L. (1999). A Resource-Based Framework for Assessing the Strategic Advantages of Family Firms. Family Business Review, 12(1), 1-25. https://doi.org/10.1111/j.1741-6248.1999.00001.x

Henssen, B., Voordeckers, W., Lambrechts, F., \& Koiranen, M. (2014). The CEO autonomystewardship behavior relationship in family firms: The mediating role of psychological ownership. Journal of Family Business Strategy, 5(3), 312-322. https://doi.org/http://dx.doi.org/10.1016/j.jfbs.2014.01.012

Hirsch, R. (2011). Decoding family businesses : are corporate governance guidelines necessary for family businesses? New Zealand business law quarterly, 17(2), 126-152.

Hirsch, R. J. (2013). The Evolution and Role of Corporate Governance Guidelines for Family Businesses: A Structural Investigation [Unpublished $\mathrm{PhD}$ thesis]. University of Auckland, New Zealand. http://hdl.handle.net/2292/21114

Hirsch-Kreinsen, H. (2015). The power of the practical: Low tech's neglected strength. University of Auckland Business Review, 18(1), 8-16.

Husted, K., \& Michailova, S. (2002). Diagnosing and fighting knowledge-sharing hostility. Organizational Dynamics, 31(1), 60-73. https://doi.org/10.1016/S0090$\underline{2616(02) 00072-4}$

Jiang, Y., \& Peng, M. W. (2011). Are family ownership and control in large firms good, bad, or irrelevant? [Article]. Asia Pacific Journal of Management, 28(1), 15-39. https://doi.org/10.1007/s10490-010-9228-2

Kang, J. K., \& Kim, J. (2020). Do family firms invest more than nonfamily firms in employeefriendly policies? Management Science, 66(3), 1300-1324. https://doi.org/10.1287/mnsc.2018.3231

Keating, N. C., \& Little, H. M. (1997). Choosing the successor in New Zealand family farms. Family Business Review, 10(2), 157-171. https://doi.org/10.1111/j.1741$\underline{6248.1997 .00157 . \mathrm{x}}$

Kilkolly-Proffit, M. (2013). Socialisation of family businesses in women-led family businesses: Growing up with “Mentor Mum.”. University of Auckland Business Review, $16(1), 6-15$.

Kilkolly-Proffit, M. (2016). Maternal Matters: A Narrative Analysis of Mother-Daughter Family Business Dyads [Unpublished PhD thesis]. University of Auckland, New Zealand. http://hdl.handle.net/2292/36310 
KPMG. (2018). Family business - the balance for success: Colliding generational perspectives, reinvigorating successful family businesses. https://assets.kpmg/content/dam/kpmg/au/pdf/2018/family-business-survey-2018report.pdf

Kubíček, A., \& Machek, O. (2020). Intrafamily Conflicts in Family Businesses: A Systematic Review of the Literature and Agenda for Future Research. Family Business Review, 33(2), 194-227. https://doi.org/10.1177/0894486519899573

Lamb, N. H., Butler, F., \& Roundy, P. (2017). Family firms and corporate social responsibility: exploring "concerns". Journal of Strategy and Management, 10(4), 469-487. https://doi.org/10.1108/JSMA-02-2016-0010

Lewis, K., Ashby, M., Coetzer, A., Harris, C., \& Massey, C. (2005). Family, friends \& government agencies: A report on SMEs \& the support infrastructure. https://www.massey.ac.nz/massey/fms/sme/businessmeasure/SIS_Summary_Report.p df

McKinsey \& Company. (2014). Perspectives on Founder- and Family-Owned Businesses. https://www.mckinsey.com/industries/private-equity-and-principal-investors/ourinsights/perspectives-on-founder-and-family-owned-businesses

Mallett, O., \& Wapshott, R. (2017). Small business revivalism: employment relations in small and medium-sized enterprises. Work, Employment and Society, 31(4), 719-726. https://doi.org/10.1177/0950017017690503

MGI. (2007). MGI New Zealand family and private business survey. MGI and RMIT. https://www.fambiz.com.au/wp-content/uploads/06-MGI-New-Zealand-FB-Survey2007-.pdf

MGI. (2013). Not Thriving: From the dining room to the board room (The MGI Australian Family and Private Business Survey 2013). https://www.fambiz.com.au/wpcontent/uploads/08\%EF\%80\%A21-MGI-FB-Survey-20131.pdf

Miller, D., \& Le Breton-Miller, I. (2006). Family Governance and Firm Performance: Agency, Stewardship, and Capabilities. Family Business Review, 19(1), 73.

Miller, D., Steier, L. P., \& Le Breton-Miller, I. (2006). Lost in time: intergenerational succession, change and failure in family business. In P. Z. Poutziouris, K. X. Smyrnios, \& S. B. Klein (Eds.), Handbook of Research on Family Business (pp.371-387). Edward Elgar.

Moskovich, Y., \& Achouch, Y. (2017). Family home culture and management-employee relationships: Comparing two kibbutz factories. Journal of Co-operative Organization and Management, 5(2), 95-107. https://doi.org/10.1016/j.jcom.2017.08.001

Mustakallio, M., Autio, E., \& Zahra, S. A. (2002). Relational and Contractual Governance in Family Firms: Effects on Strategic Decision Making. Family Business Review, 15(3), 205-222. https://doi.org/https://doi.org/10.1111/j.1741-6248.2002.00205.x 
Neubaum, D. O. (2018a). Family Business Research: Roads Travelled and the Search for Unworn Paths. Family Business Review, 31(3), 259-270. https://doi.org/10.1177/0894486518792948

Neubaum, D. O. (2018b). Research on the human resource practices of family businesses: A domain worthy of further study. Human Resource Management, 57(5), 955-956. https://doi.org/https://doi.org/10.1002/hrm.21939

New Zealand Government. (2016). Small and Medium Businesses in New Zealand: Report of the Small Business Development Group.

https://www.mbie.govt.nz/assets/90fcb52f9f/small-business-development-group2016-report.pdf

Payne, G. T. (2018). Reflections on Family Business Research: Considering Domains and Theory. Family Business Review, 31(2), 167-175. https://doi.org/10.1177/0894486518776550

Pearson, A. W., Carr, J. C., \& Shaw, J. C. (2008). Toward a theory of familiness: A social capital perspective. Entrepreneurship: Theory \& Practice, 32(6), 949-969. https://doi.org/10.1111/j.1540-6520.2008.00265.x

Peng, M. W., \& Jiang, Y. (2010). Institutions behind family ownership and control in large firms. Journal of Management Studies, 47(2), 253-273. https://doi.org/10.1111/j.14676486.2009.00890.x

Peng, M. W., Sun, W., Vlas, C., Minichilli, A., \& Corbetta, G. (2018). An institution-based view of large family firms: A recap and overview [Article]. Entrepreneurship: Theory and Practice, 42(2), 157-205. https://doi.org/10.1177/1042258717749234

PwC. (2016). Finding balance: How New Zealand family businesses are responding to a changing world. https://www.pwc.co.nz/pdfs/Family-Business-Survey-2016.pdf

PwC. (2021). From trust to impact: Why family businesses need to act now to ensure their legacy tomorrow. https://www.pwc.com/gx/en/family-business-services/familybusiness-survey-2021/pwc-family-business-survey-2021.pdf

Rainnie, A. (1989). Industrial Relations in Small Firms: Small Isn't Beautiful. Routledge.

Ram, M. (2001). Family Dynamics in a Small Consultancy Firm: A Case Study. Human Relations, 54(4), 395-418. https://doi.org/10.1177/0018726701544001

Ram, M., \& Edwards, P. (2003). Praising Caesar not burying him: what we know about employment relations in small firms. Work, Employment and Society 17(4), 719-730.

Ram, M., Edwards, P., Gilman, M., \& Arrowsmith, J. (2001). The Dynamics of Informality: Employment Relations in Small Firms and the Effects of Regulatory Change. Work, Employment and Society, 15(4), 845-861. https://doi.org/10.1017/S0950017001008455

Rantanen, N., \& Jussila, I. (2011). F-CPO: A collective psychological ownership approach to capturing realized family influence on business. Journal of Family Business Strategy, 2(3), 139-150. https://doi.org/http://dx.doi.org/10.1016/j.jfbs.2011.07.005 
Rasmussen, E., Foster, B., \& Farr, D. (2016). The battle over employers' demand for "more flexibility". Employee Relations, 38(6), 886-906. https://doi.org/10.1108/ER-12-2015-0226

Schulze, W. S., Lubatkin, M. H., Dino, R. N., \& Buchholtz, A. K. (2001). Agency Relationships in Family Firms: Theory and Evidence. Organization Science, 12(2), 99116. https://doi.org/10.1287/orsc.12.2.99.10114

Sieger, P., Bernhard, F., \& Frey, U. (2011). Affective commitment and job satisfaction among non-family employees: Investigating the roles of justice perceptions and psychological ownership. Journal of Family Business Strategy, 2(2), 78-89. https://doi.org/10.1016/j.jfbs.2011.03.003

Small Business Council. (2019). Defining Small Business: Recommendations of the New Zealand Small Business Council for the Minister of Small Business. https://www.mbie.govt.nz/assets/defining-small-business.pdf

Soleimanof, S., Rutherford, M. W., \& Webb, J. W. (2018). The Intersection of Family Firms and Institutional Contexts: A Review and Agenda for Future Research. Family Business Review, 31(1), 32-53. https://doi.org/10.1177/0894486517736446

Stewart, A., \& Hitt, M. A. (2012, Mar). Why Can't a Family Business Be More Like a Nonfamily Business?: Modes of Professionalization in Family Firms. Family Business Review, 25(1), 58-86. https://doi.org/https://doi.org/10.1177/0894486511421665

Tabor, W., Chrisman, J. J., Madison, K., \& Vardaman, J. M. (2018). Nonfamily Members in Family Firms: A Review and Future Research Agenda. Family Business Review, 31(1), 54-79. https://doi.org/10.1177/0894486517734683

Tagiuri, R., \& Davis, J. A. (1996). Bivalent attributes of the family firm. Family Business Review, 9(2), 199-207. https://doi.org/10.1111/j.1741-6248.1996.00199.x

Teixeira, S., Veiga, P. M., Figueiredo, R., Fernandes, C., Ferreira, J. J., \& Raposo, M. (2020, 04/16/). A systematic literature review on family business: insights from an Asian context. Journal of Family Business Management, 10(4), 329-348. https://doi.org/10.1108/JFBM-12-2019-0078

Tharawat. (2016, June 1). Economic impact of family businesses - A compilation of facts. Tharawat Magazine. https://www.tharawat-magazine.com/economic-impact-familybusinesses/economic-impact-family-businesses-2/

Whittaker, H., Fath, B., Fiedler, A., \& Simmons, G. (2011). Growing New Zealand Businesses: Summary of survey findings. New Zealand Asia Institute, University of Auckland. https://cdn.auckland.ac.nz/assets/business/about/our-research/researchgroups/gnzb/2011-gnzb-survey-findings/gnzb-survey-findings-15-aug-2011.pdf

Woodfield, P. J. (2012). Intergenerational Entrepreneurship in Family Business: Conceptualising ways Entrepreneurial Family Businesses can be Sustained across Generations [Unpublished $\mathrm{PhD}$ thesis]. University of Auckland, New Zealand. https://researchspace.auckland.ac.nz/handle/2292/19446 
Woodfield, P. J., \& Husted, K. (2017). Intergenerational knowledge sharing in family firms: Case-based evidence from the New Zealand wine industry. Journal of Family Business Strategy, 8(1), 57-69. https://doi.org/10.1016/j.jfbs.2017.01.001

Woodfield, P. J., \& Husted, K. (2019). How does knowledge sharing across generations impact innovation? International Journal of Innovation Management, 23(08), 17. https://doi.org/10.1142/S1363919619400048

Woodfield, P. J., Shepherd, D., \& Woods, C. (2017a). How can family winegrowing businesses be sustained across generations? International Journal of Wine Business Research, 29(2). https://doi.org/10.1108/IJWBR-12-2015-0052

Woodfield, P. J., Woods, C., \& Shepherd, D. (2017b). Sustainable entrepreneurship: another avenue for family business scholarship? Journal of Family Business Management, 7(1), 122-132. https://doi.org/10.1108/JFBM-12-2015-0040

Wu, N. (2020). Small Is Beautiful or Big Is Better: How Much Do Industry and Family Ownership Matter in Firms of Different Sizes? European Management Review, 17(4), 977-991. https://doi.org/10.1111/emre.12408 